\title{
Rancang Bangun Electronic Costumer Relationship Management (E-CRM) Sebagai Sistem Informasi Dalam Peningkatan Layanan Perpustakaan Digital SMAN 1 Sakra
}

\author{
Surni Erniwati ${ }^{1}$, Zaeniah $^{2}$ \\ Universitas Teknologi Mataran ${ }^{1,2}$ \\ surnierniwati@utmmataram.ac.id, zaen1989@gmail.com
}

\begin{abstract}
Abstrak - Perpustakaan bagian yang sangat erat kaitannya dengan siswa, dimana perpustakaan sebagai tempat menyediakan literatur-literatur yang mendukung kegiatan pembelajaran. Selain siswa, guru, mahasiswa, dosen dan masyarakat sangat membutuhkan perpustakaan yang menyediakan literatur-literatur untuk mendukung dalam pembelajaran. Perpustakaan pada umumnya seperti gudang buku, di mana buku-buku, jurnal, hasil penelitian dan majalah berada di rak-rak yang tertata dengan sangat rapi. Sehingga untuk membacanya harus datang ke perpustakaan dan mencari buku yang butuhkan. Dengan perkembangan teknologi informasi, perpustakaan dituntut untuk menyediakan sumber-sumber informasi dalam bentuk elektronik. Pemanfaatan informasi dalam bentuk elektronik saat ini sudah menjadi bagian dari gaya hidup modern masyarakat. Hal ini harus dilakukan untuk memenuhi tuntutan terhadap mutu layanan perpustakaan, resource sharing, mengefektifkan sumber daya manusia, efisiensi waktu dan keragaman informasi yang dikelola. Perpustakaan yang baik adalah perpustakaan yang menerapkann konsep E-CRM. Customer Relationship Management (CRM) yang merupakan strategi untuk memperoleh, mengkonsolidasi, menganalisa data, untuk kemudian digunakan untuk berinteraksi dengan customer (pengguna perpustakaan: siswa, mahasiswa, guru, dosen, dan masyarakat), dengan demikian akan tercipta suatu pandangan yang komprehensif terhadap customer dan hubungan yang lebih baik dengan customer sedangkan E-CRM merupakan CRM yang diterapkan secara elektronik dengan menggunakan web browser, internet dan media elektronik lainnya.
\end{abstract}

Kata kunci: E-CRM; perpustakaan digital; Sistem Informasi

\begin{abstract}
The library section is very closely related to students, where the library as a place to provide literature that supports learning activities. In addition to students, teachers, students, lecturers and the community really need a library that provides literature to support learning. Libraries in general are like a book warehouse, where books, journals, research results and magazines are on very neatly arranged shelves. So to read it you have to come to the library and look for the books you need. With the development of information technology, libraries are required to provide information sources in electronic form. Utilization of information in electronic form is now a part of people's modern lifestyles. This must be done to meet the demands on the quality of library services, resource sharing, effective human resources, time efficiency and diversity of information that is managed. A good library is a library that applies the concept of E-CRM. Customer Relationship Management (CRM) which is a strategy to obtain, consolidate, analyze data, and then be used to interact with customers (library users: students, students, teachers, lecturers, and the public), thus creating a comprehensive view of the customer and better relationships with customers while E-CRM is a CRM that is implemented electronically using a web browser, internet and other electronic media.
\end{abstract}

Keywords: E-CRM; digital library; Information Systems

\section{Latar Belakang}

Perkembangan teknologi informasi saat ini telah memasuki semua bidang kehidupan, hal ini dapat dilihat dengan banyak pengguna komputer baik untuk kepentingan pribadi, kantor, perusahaan atau bisnis bahkan sampai kepada hal-hal yang bersifat hiburan dan pendidikan [1]. efek dari perkembangan teknologi internet adalah semakin banyaknya komputer atau komputerisasi di dalam pengolahan data pada instansi-instansi pemerintah maupun swasta khususnya instansi bidang pendidikan. Perpustakaan digital untuk memenuhi kebutuhan dalam search referensi yang dibutuhkan dalam proses belajar mengajar, penelitan dan pengabdian [1]. Selain itu perpustakaan adalah bagian yang tidak terlepas dari pelajar dimana sebagai tempat menyediakan literaturliteratur yang mendukung kegiatan pembelajaran sampai dengan tugas akhir atau skripsi.

Customer Relationship Management (CRM) merupakan strategi untuk memperoleh, mengkonsolidasi, menganalisa data, untuk kemudian digunakan untuk berinteraksi

Rancang Bangun Electronic Costumer Relationship Management (E-CRM) Sebagai Sistem Informasi Dalam Peningkatan Layanan Perpustakaan Digital SMAN 1 Sakra 
dengan customer yaitu siswa, mahasiswa, guru, dosen, dan masyarakat umum, dengan demikian akan tercipta suatu pandangan yang komprehensif terhadap customer dan hubungan yang lebih baik dengan customer [14]. Menurut [17] CRM merupakan proses mengelola informasi secara detail tentang masing-masing customer dan secara cermat mengelola semua titik sentuhan customer demi memaksimalkan kesetiaan pelanggan. Sehingga penerapan dengan CRM dapat menggambarkan proses interaksi customer dengan perpustakaan digital. Dari konsep ECRM dapat meningkatkan loyalitas customer (pengguna perpustakaan: siswa, mahasiswa, guru, dosen, dan masyarakat) untuk minat membaca. Tentunya hal itu dapat terjadi dengan menerapkan konsep CRM. Menurut peneliti hal ini sangat menarik untuk diteliti, sehingga dengan hasil penelitian ini nantinya dapat menumbuhkan minat membaca dan kemudahan dalam mengakses semua data yang ada pada perpustakaan digital dan memberikan rasa kepuasan dan kenyamanan atas layanan perpustakaan digital. Dengan konsep E-CRM dapat memaksimalkan layanan perpustakaan digital di SMAN 1 Sakra.

\section{Kajian Pustaka}

\section{A. Teknologi Informasi}

Dengan perkembangan teknologi informasi, perpustakaan dituntut untuk menyediakan sumber-sumber informasi dalam bentuk elektronik. Pemanfaatan informasi dalam bentuk elektronik saat ini sudah menjadi bagian dari gaya hidup modern masyarakat. $\mathrm{Hal}$ ini harus dilakukan untuk memenuhi tuntutan terhadap mutu layanan perpustakaan, resource sharing, mengefektifkan SDM, efisiensi waktu dan keragaman informasi yang dikelola [8]. Penerapan teknologi informasi sebagai sarana untuk menyimpan, mendapatkan dan menyebarluaskan informasi ilmu pengetahuan dalam format digital, dimana isi dari perpustakaan digital berada dalam suatu komputer server yang bisa di tempatkan secara lokal, maupun di lokasi yang jauh, namun dapat diakses dengan cepat dan mudah melalui jaringan komputer. Bentuk penerapan teknologi informasi dalam perpustakaan dikenal dengan istilah perpustakaan digital. Penerapan teknologi informasi pada perpustakaan dipengaruhi oleh beberapa faktor yaitu:

a. Kemudahan mendapatkan produk teknologi informasi

b. Harga semakin terjangkau untuk memperoleh produk teknologi informasi c. Kemampuan dari teknologi informasi

d. Tuntutan layanan masyarakat serba "klik"

e. Mengefisiensikan dan mempermudah pekerjaan dalam perpustakaan memberikan layanan yang lebih baik kepada pengguna perpustakaan meningkatkan citra perpustakaan,

f. Pengembangan infrastruktur nasional, regional dan globa [2].

Menurut [4] penerapan teknologi informasi di perpustakaan dapat difungsikan dalam dua bentuk yaitu:

(a) Penerapan teknologi informasi digunakan sebagai sistem informasi manajemen perpustakaan, mulai dari pengadaan, inventarisasi, katalogisasi, sirkulasi bahan pustaka, pengelolaan anggota, statistik.

(b) Penerapan teknologi informasi sebagai sarana untuk menyimpan, mendapatkan dan menyebarluaskan informasi ilmu pengetahuan dalam format digital. Penerapan teknologi informasi pada perpustakaan digital dengan konsep ECRM merupakan metode baru untuk mempertahankan minat membaca baik siswa, mahasiswa, guru, dosen untuk menunjang kegiatan pendidikan. Dan juga dapat menarik minat membaca masyarakat karena layanan yang maksimal. Dengan konsep E-CRM, perangkat lunak yang dibangun dapat memberikan layanan kepada pembaca dengan maksimal dan dapat memberikan rasa kepuasan dan kenyamanan pembaca. Sehingga para pembaca dengan mudah mendapatkan literatur-literatur yang dibutuhkan

\section{B. Perpustakaan Digital}

Layanan perpustakaan digital dapat mempermudah pencarian informasi di dalam koleksi objek informasi seperti dokumen, gambar dan database dalam format digital dengan cepat, tepat dan akurat. Perpustakaan digital tidak berdiri sendiri melainkan terkain dengan sumber-sumber lain dan pelayanan informasinya terbuka bagi pengguna di seluruh dunia. Koleksi perpustkaan digital tidaklah terbatas pada dokumen elektronik penggnati bantuk cetak, ruang lingkup koleksinya sampai pada artefak digital yang tidak bisa digantikan dalam bentuk cetak. Koleksi perpustakaan digital lebih ditekankan pada isi informasi, jenis dokumen tradisional sampai hasil penelusuran. Perpustakaan digital melayani mesin, manajer informasi dan pemakai informasi [11]. Menurut [13] gagasan perpustakaan digital diikuti Kantor Kementrian Riset dan Teknologi dengan Program Perpustakaan digital yang diarahkan memberi 
kemudahan akses dokumentasi data ilmiah dann teknologi dalam bentuk digital secara terpadu dan lebih dinamis. Upaya ini dilaksanakan untuk mendokumentasikan berbagai produk intelektual seperti tesis, disertasi, laporan penelitian, dan juga publikasi ilmiah lainnya.

Menurut [5] beberapa keunggulan perpustakaan digital diantaranya adalah sebagai berikut:

a. Long distance service, artinya dengan perpustakaan digital, pengguna bisa menikmati layanan sepuasnya, kapanpun dan dimanapun.

b. Akses yang mudah. Akses pepustakaan digital lebih mudah dibanding dengan perpustakaan konvensional, karena pengguna tidak perlu dipusingkan dengan mencari di katalog dengan waktu yang lama.

c. Murah (cost efective). Perpustakan digital tidak memerlukan banyak biaya. Mendigitalkan koleksi perpustakaan lebih murah dibandingkan dengan.

d. Mencegah duplikasi dan plagiat. Perpustakaan digital lebih "aman", sehingga tidak akan mudah untuh diplagiat. Bila penyimpanan koleksi perpustakaan menggunakan format PDF, koleksi perpustakaan hanya bisa dibaca oleh pengguna, tanpa bisa mengeditnya membeli buku.

e. Publikasi karya secara global. Dengan adanya perpustakaan digital, karyakarya dapat dipublikasikan secara global ke seluruh dunia dengan bantuan internet

\section{E-CRM}

E-CRM merupakan singkatan dari Electronic Customer Relationship Management merupakan strategi yang menggunakan teknologi informasi yang memberikan perpustakaan suatu pandangan customer (pengguna perpustakaan: siswa, mahasiswa, guru, dosen, dan masyarakat) secara luas, yang dapat dihandalkan dan berintegrasi sehingga semua proses dan interaksi customer (pengguna perpustakaan: siswa, mahasiswa, guru, dosen, dan masyarakat) membantu dalam mempertahankan minat membaca dan memperluas hubungan yang menguntungkan secara bersama. E-CRM merupakan CRM yang berbasis pada teknologi-teknologi yang melibatkan elektronik serta online mode di dunia maya dan juga mobile. E-CRM juga merupakan gabungan konsep-konsep teknologi yang berkembangn untuk mengolah dan menganalisa hubungan antara perpustakaan dengan customer (pengguna perpustakaan: siswa, mahasiswa, guru, dosen, dan masyarakat)

Konsep dari E-CRM adalah sense and response Marketing, yaitu pendekatan relevansi, contextual marketing cummunication yang memantau perilaku customer (pengguna perpustakaan: siswa, mahasiswa, guru, dosen, dan masyarakat). Keuntungan dengan konsep E-CRM adalah dapat membangun hubungan dengan customer (pengguna perpustakaan: siswa, mahasiswa, guru, dosen, dan masyarakat) untuk jangka waktu yang lama. Dalam E-CRM terdapat konsep Relationship Marketing, yang maksudnya adalah perpustakaan memberikan informasi dan melayani customer (pengguna perpustakaan: siswa, mahasiswa, guru, dosen, dan masyarakat), sesuai dengan karakteristik yang di miliki oleh customer. Hal ini dilakukan untuk membentuk sikap loyalitas, yang dimulai dari permission dan juga kepercayaan. Sikap yang akan ditunjukkan ini sesuai dengan basic marketing yaitu identifying, anticipating dan satisfying [19]. E-CRM merupakan CRM yang diterapkan secara elektronik dengan menggunakan web browser, internet dan media elektronik laiannya seperti: email, call center, sms gateway, chatt). Alat-alat yang digunakan untuk mendukung E-CRM adalah:

a. Personalized Web Page merupakan Web page (halaman web) dapat digunakan untuk mencatat kegiatan dan preferensi customer

b. FAQs merupakan Fitur Frequently Asked Questions (FAQs) adalah sebuah tool yang sederhana yang bisa digunakan untuk menangani pertanyaan customer yang berulang

c. Tracking Tools merupakan tool yang digunakan oleh konsumen untuk mengetahui pemesanan (order) yang telah dilakukan sehingga menghemat waktu dan biaya perusahaan. Contoh: mengecek judul buku

d. EMail dan Automated Response digunakan untuk mengirimkan informasi, konfirmasi dan membangun korespondensi dengan customer.

e. Help Desk atau Call Center berfungsi sebagai customer service yang biasanya menggunakan fasilitas telepon, faximili, atau email

f. Troubleshooting Tools merupakan tool yang disediakan perusahaan untuk membantu customer memecahkan persolan yang dihadapi sendiri. Contohnya perpustakaan menyediakan software trouble-shooting untuk membantu customer menyelesaikan masalahnya. 


\section{Metode Penelitian / Perancangan Sistem}

a. Metode Pengembangan Perangkat Lunak Metode yang digunakan dalam pengembangan perangkat lunak adalah menggunakan metode waterfall. Metod waterfall merupakan metode pengembangan perangkat lunak yang sistematik dan sekuensial yang mulai pada tingkat dan kemajuan system sampai pada analisis, desain, kode, test dan pemeliharaan.

b. Teknik Pengumpulan Data

1) Observasi

Observasi dilakukan dengan pengamatan langsung pada SMAN 1 Sakra pada khususnya dan masyarakat pada umumnya serta mencatatat datadata yang berhubungan dengan pengelolaan barang.

2) Wawancara

Wawancara dilakukan dengan berkomunikasi langsung dengan pihakpihak yang terkait pada bank BRI Unit Pemenang.

3) Studi Pustaka

Studi pustaka adalah suatu pembahasan yang berdasarkan pada buku-buku referensi yang bertujuan untuk memperkuat materi pembahasan maupun sebagai dasar untuk menggunakan rumus-rumus tertentu dalam menganalisa dan mendesain suatu struktur.

\section{Implementasi Sistem dan Hasil}

Penelitian E-CRM sebagai sistem informasi dalam peningkatan layanan perpustakaan digital SMAN 1 Sakra merupakan penelitian tentang bagaimana cara perpustakaan dapat meningkatkan layanan perpustakaan terhadap siswa. Tentunya layanan itu dapat ditingkatkan dengan penerapan teknologi digital dan konsep E-CRM. Hasil dari penelitian ini adalah berupa perangkat lunak yang dapat digunakan untuk dapat memberikan layanan perpustakaan. Sehingga stakholder merasa puas terhadap layanan pada suatu perpustakaan. Disamping itu dengan adanya hasil penelitian ini dapat meningkatkan pengunjung perpustakaan baik secara manual ataupun secara sistem informasi online. Sistem informasi E-CRM yang dihasilkan pada layanan perpustakaan khususnya perpustakaan SMAN 1 Sakra. Penerapan ECRM terhadap perpustakaan digital dapat meningkatkan kualitas pelayanan terhadap pengguna. Dengan konsep E-CRM maka dapat membantu siswa, dosen, guru, peneliti untuk mencari literatur-literatur. Produk IT berupa model perangkat lunak perpustakaan berbasis teknologi informasi untuk meningkatkan kinerja layanan perpustakaan dan mewujudkan perpustakaan berbasis digital dengan konsep E-CRM. Yaitu:

(1) Bagi pengguna layanan perpustakaan, dapat memudahkan pengguna layanan perpustakaan dalam mencari informasi koleksi bahan pustaka tanpa harus datang ke perpustakaan karena dapat diakses melalui internet. Dapat merasakan kepuasan atas pelayanan, dan kenyamanan karena diterapkannya konsep E-CRM, sehingga menciptakan atau menambah minat membaca;

(2) Pengguna layanan perpustakaan dapat dengan mudah mengakses semua informasi perpustakaan, karena dapat diakses dimanapun, kapanpun tanpa terbatas dengan ruang dan waktu;

(3) Pengelola perpustakaan dapat memonitoring pelayanan perpustakaan, sehingga jika terjadi ketidakpuasan user, dapat langsung dilakukan evaluasi;

(4) Dapat menjalin relasi dengan perpustakaan universitas lain, bahkan bisa menjalin relasi dengan perpustakaan universitas luar negeri;

(5) Pengguna perspustakaan akan mendapatkan update data perpustakaan secara real time. Misalnya ada buku terbaru, jurnal terbaru atau majalah terbaru. Dengan update informasi secara real time maka akan dapat menarik minat membaca.

Adapun hasil dari Rancang Bangun Electronic Costumer Relationship Management (E-CRM) Sebagai Sistem Informasi Dalam Peningkatan Layanan Perpustakaan Digital SMAN 1 Sakra sebagai berikut :

1 Halaman Home

Pada saat halaman web Perpustakaan Digital pertama kali diakses, halaman pertama yang akan muncul adalah halaman Home dari aplikasi. Pada sebelah kanan website terdapat form login yang bisa digunakan anggota untuk melakukan login diaplikasi agar bisa melakukan unduh. Untuk melakukan login, harus memasukkan username dan password pada form login, setelah berhasil login akan dialihkan ke halaman yang berbeda sesuai dengan level hak akses

Rancang Bangun Electronic Costumer Relationship Management (E-CRM) Sebagai Sistem Informasi Dalam Peningkatan Layanan Perpustakaan Digital SMAN 1 Sakra 


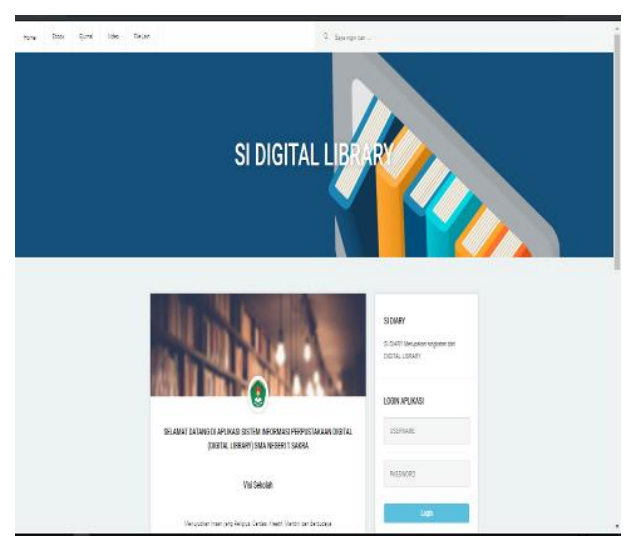

Gambar 1. Halaman Home

\section{Halaman home setelah login}

Setelah berhasil login, akan diarahkan ke halaman web perpustakaan digital sesuai dengan level hak akses, diantaranya adalah mengunduh ebook, mengunduh file ejurnal, mengunduh file lain, menonton video, melihat riwayat unduh dan mengganti kata sandi akun perpustakaan digital.

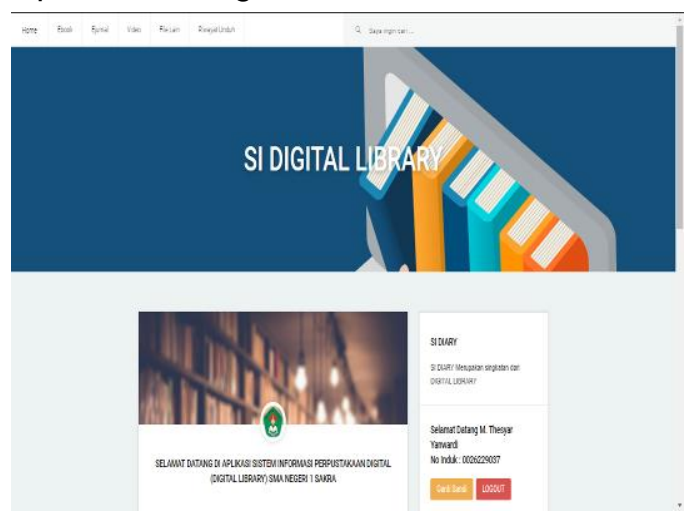

Gambar 2. Halaman home setelah login

\section{Halaman Ebook}

Pada halaman Ebook akan ditampilkan jenisjenis buku yang ada seperti gambar 4.3.

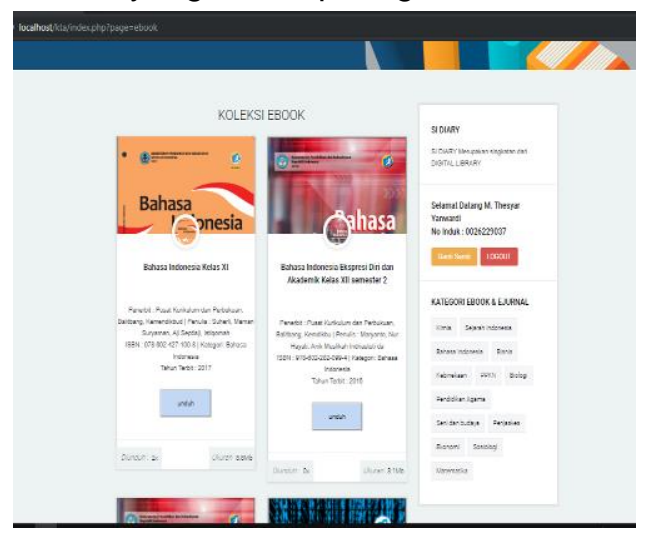

Gambar 3. Halaman E-Book
4 Halaman proses unduh Ebook

Setelah mengklik button unduh, maka secara otomatis halaman proses unduh tampil, apabila user menggunakan IDM (Internet Download Manager) maka tampilannya seperti dibawah ini, apabila seperti ini user hanya perlu menekan tombol Start Download maka proses unduh dimulai dan jika tidak menggunakan IDM (Internet Download Manager) maka proses unduh dilakukan secara langsung tidak memberikan konfirmasi unduh seperti gambar 4.4

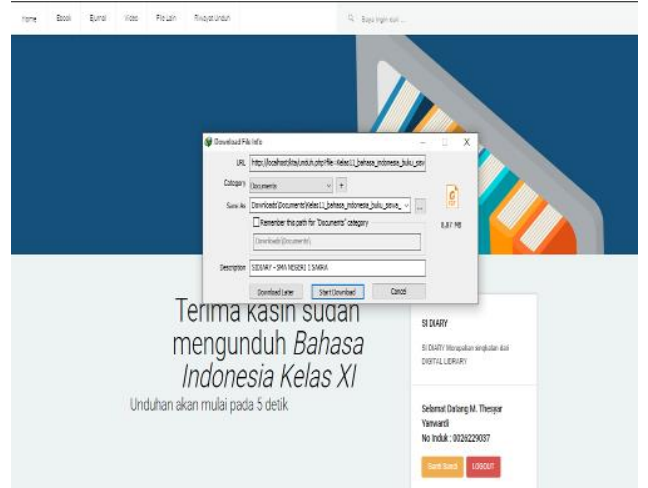

Gambar 4. Halaman proses unduh Ebook

\section{Halaman Ejurnal}

Pada halaman Ejurnal akan menampilkan jenis-jenis jurnal yang terdapat didalam perpustakaan digital seperti gambar 4.5.

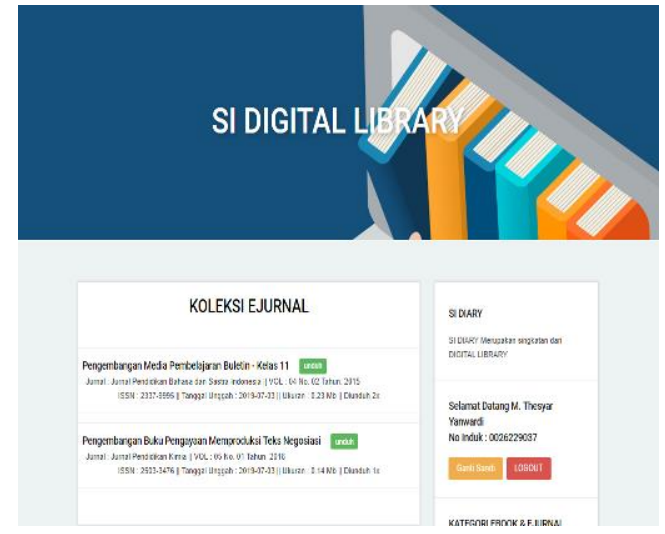

Gambar 5. Halaman Ejurnal

6 Halaman proses unduh Ejurnal

Setelah mengklik button unduh, secara otomatis halaman proses unduh tampil, apabila user menggunakan IDM (Internet Download Manager) maka tampilannya seperti dibawah ini, apabila seperti ini user hanya perlu menekan tombol Start Download maka proses unduh dimulai dan jika tidak menggunakan IDM (Internet Download Manager) maka proses unduh dilakukan 
secara langsung tidak memberikan konfirmasi unduh seperti gambar 4.6

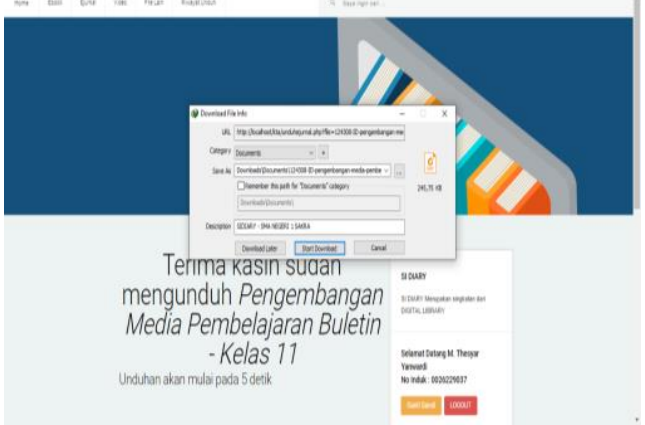

Gambar 6. Halaman Unduh Ejurnal

\section{Halaman ganti kata sandi}

Jika user ingin mengganti kata sandi, user hanya perlu mengklik tombol ganti sandi yang terletak di sebelah tombol logout, setelah mengklik tombol tersebut, akan tampil form ganti kata sandi, cara mengganti sandi cukup mudah, masukkan password lama pada kolom yang disediakan kemudian masukkan password baru pada kolom yang disediakan juga dan masukkan juga konfirmasi password pada kolom yang disediakan kemudian user menekan tombol Ubah Sandi, apabila user memasukkan password lama yang berbeda maka sistem akan memberikan pemberitahuan bahwa password lama tidak cocok, apabila user juga memasukkan password baru dengan konfirmasi password yang berbeda maka sistem akan memberitahu bahwa password baru dan konfirmasi password cocok, apabila user juga mengganti password baru dengan password yang kurang dari 5 karakter maka, sistem akan memberitahukan bahwa password minimal 5 karakter, jadi untuk mengganti password harus minimal lebih dari 5 karakter, password lama harus benar dan password baru dengan konfirmasi password juga harus sama.

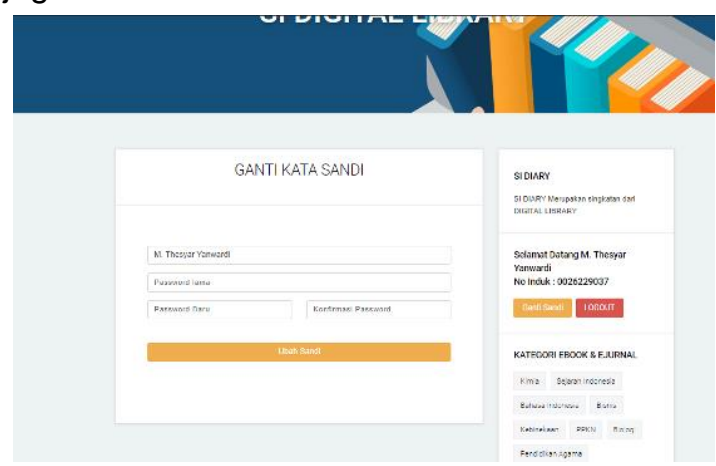

Gambar 7. Halaman Ganti Kata Sandi
8 Halaman lihat data berdasarkan kategori Jika user ingin mencari file berdasarkan kategori user dapat memilih kategori yang terdapat pada sebelah kanan bawah aplikasi, setelah salah satu kategori dipilih, maka file akan tampil.

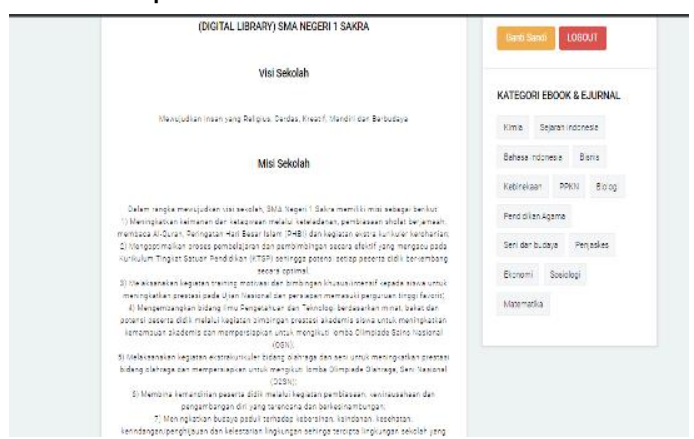

Gambar 8. Halam lihat data berdasarkan kategori

\section{Halaman Cari data}

Ketika user memasukkan kata kunci pencarian data pada form cari di sebelah kanan atas dari aplikasi maka akan tampil data yang dicari apabila data tersebut ada didalam aplikasi, seperti gambar dibawah ini

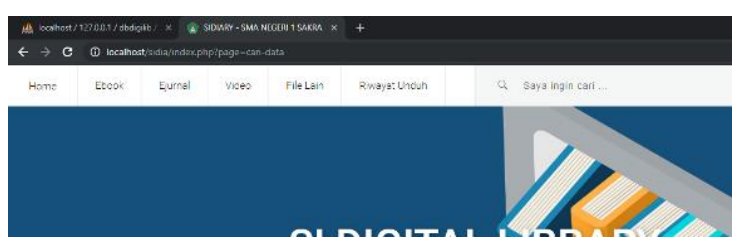

Gambar 9. Halaman Cari Data

10 Halaman Riwayat Unduh

Ketika user menekan menu riwayat unduh maka akan tampil seperti gambar 4.10, akan tampil semua file yang pernah diunduh oleh user, user dapat mengunduh file lagi dengan menekan tombol unduh

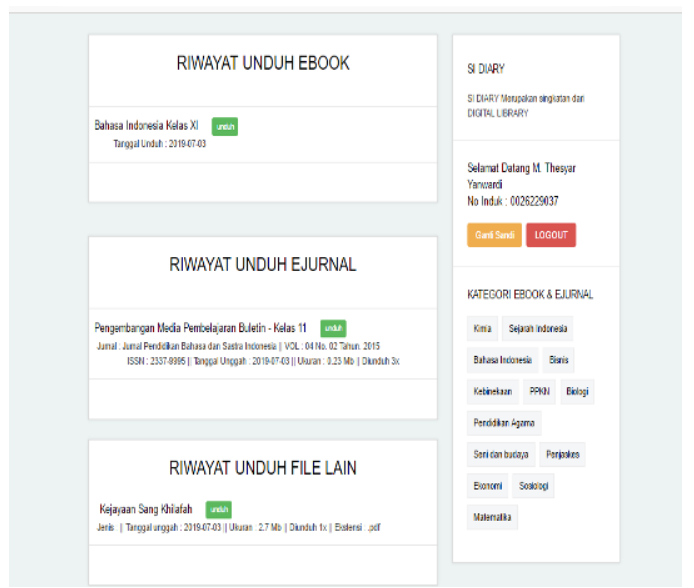

Gambar 10. Halaman Riwayat Unduh

Rancang Bangun Electronic Costumer Relationship Management (E-CRM) Sebagai Sistem Informasi Dalam Peningkatan Layanan Perpustakaan Digital SMAN 1 Sakra 


\section{Flowchart Program}

1. Flowchart Beranda

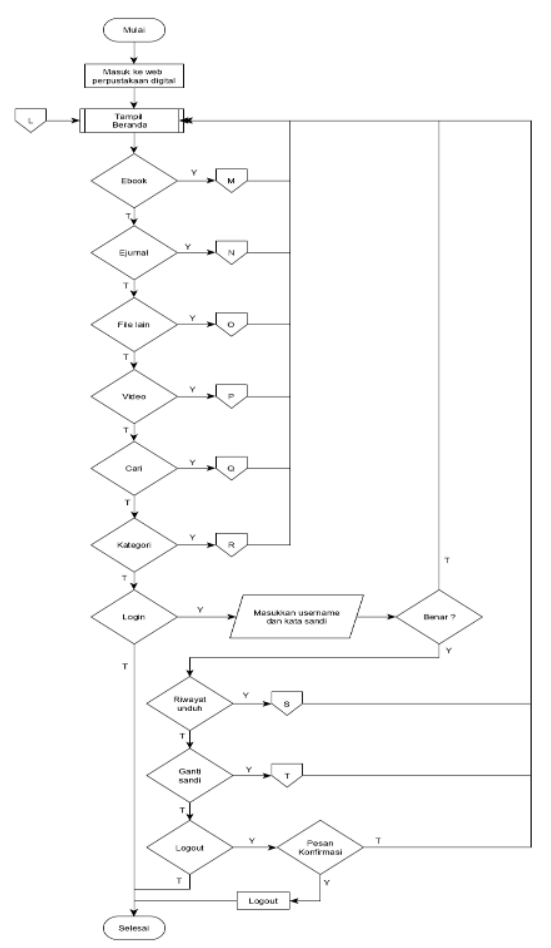

Gambar 11. Flowchart Beranda

2. Flowchart ebook

Berikut merupakan flowchart ebook

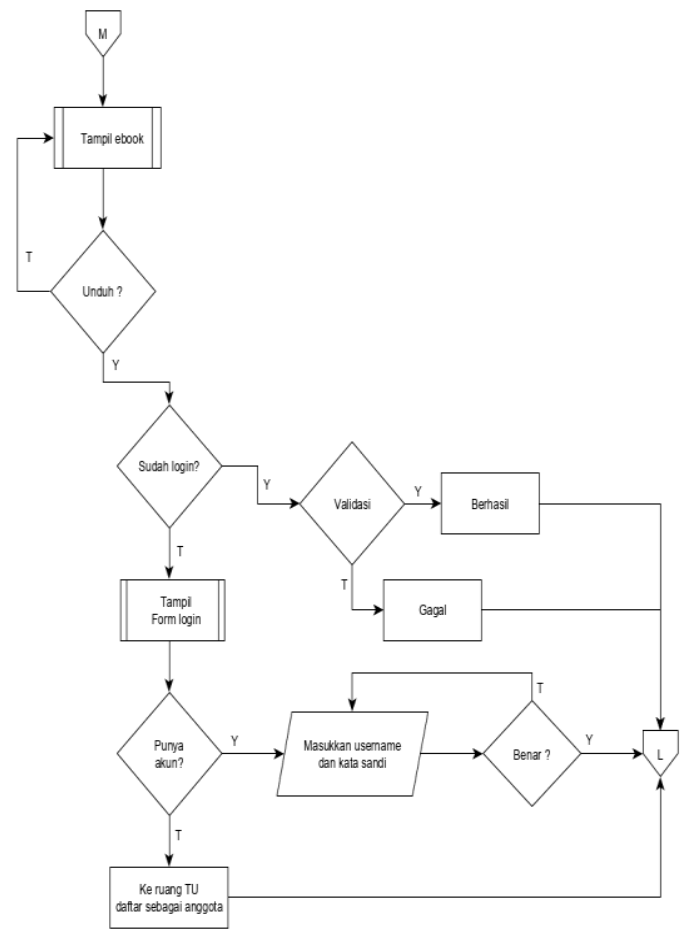

Gambar 12. Flowchart Ebook
3. Flowchart ejurnal

Berikut merupakan flowchart ejurnal

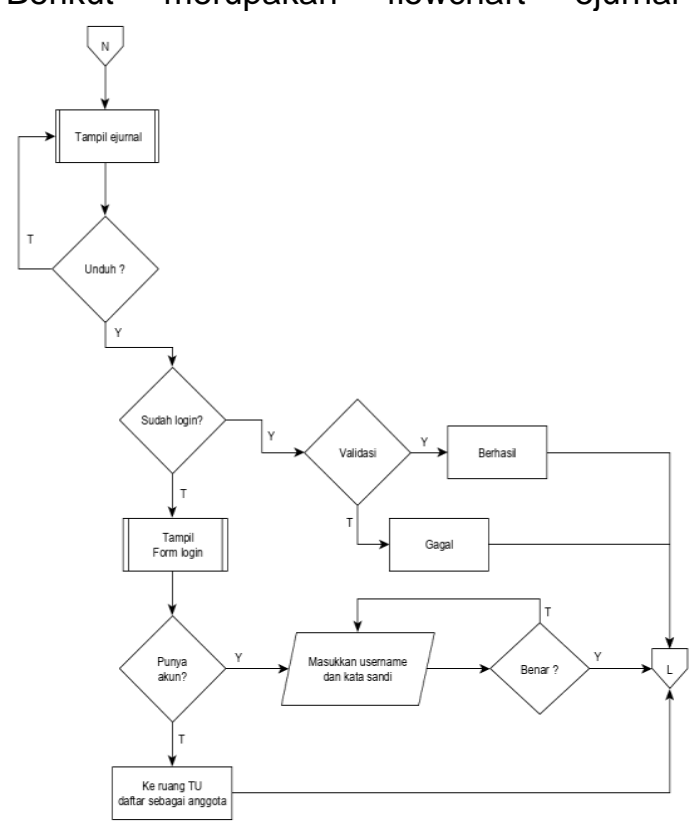

Gambar 13. Flowchart Ejurnal

4. Flowchart cari

Berikut merupakan flowchart cari

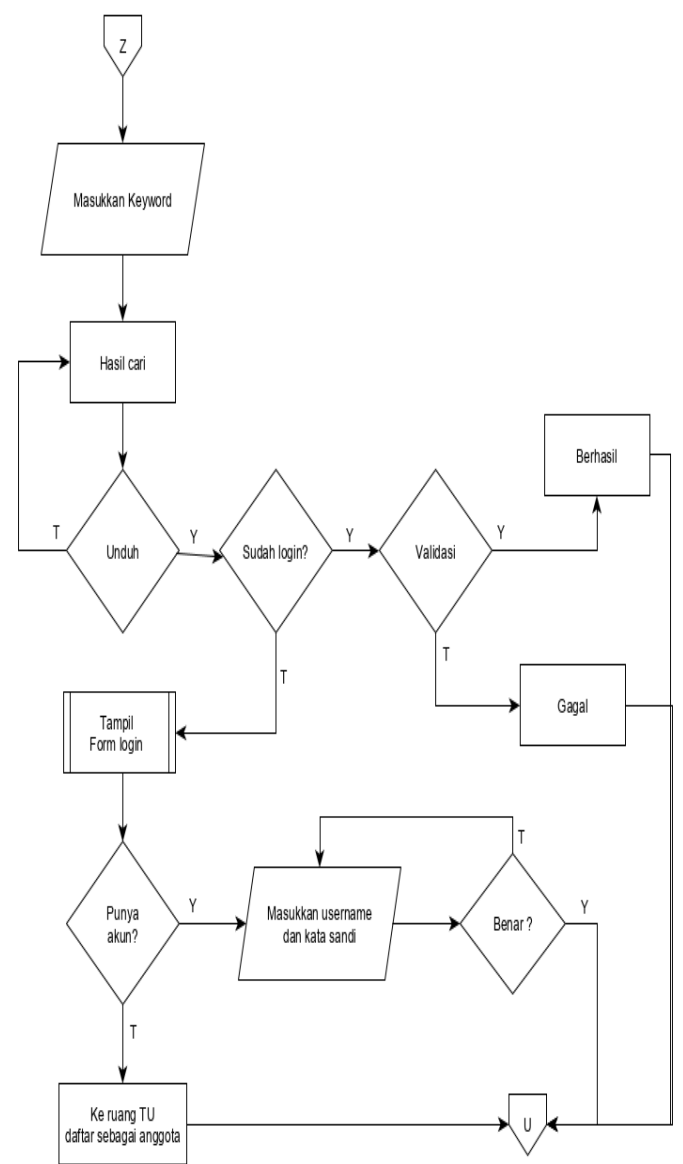

Gambar 14. Flowchart Cari

Rancang Bangun Electronic Costumer Relationship Management (E-CRM) Sebagai Sistem Informasi Dalam Peningkatan Layanan Perpustakaan Digital SMAN 1 Sakra 
5. Flowchart kategori

Berikut merupakan flowchart kategori

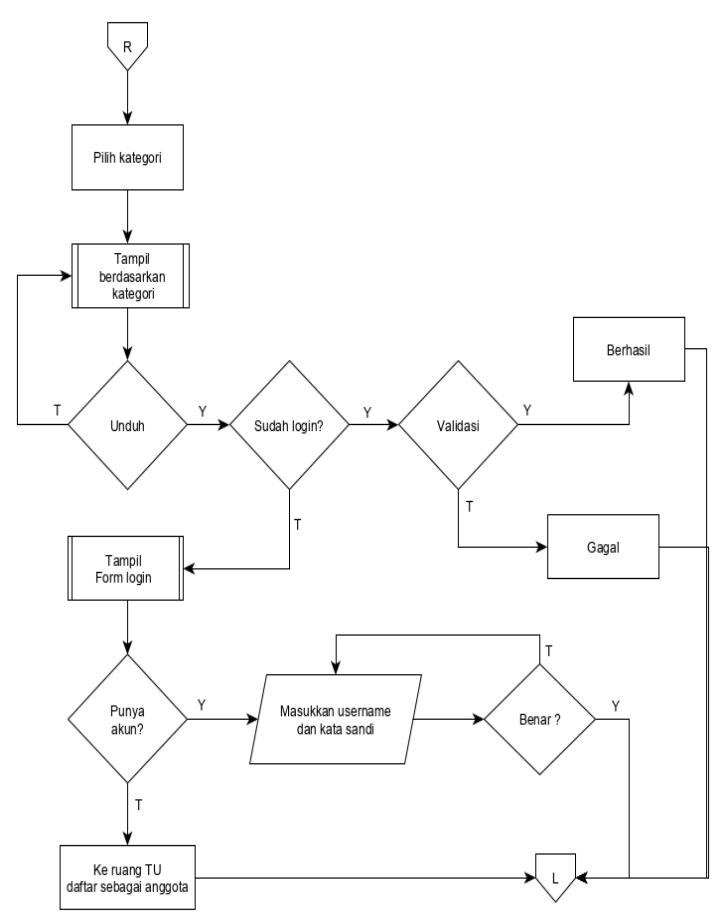

Gambar 15. Flowchart Kategori

6. Flowchart ganti sandi

Berikut merupakan flowchart ganti sandi

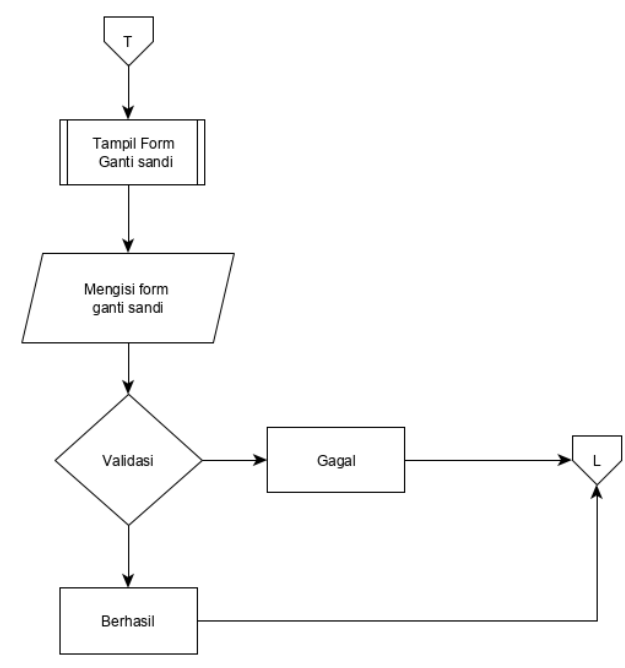

Gambar 16. Flowchart Ganti Sandi

\section{Kesimpulan}

Berdasarkan hasil penelitian yang sudah dicapai maka, dengan adanya sistem yang dibuat dapat meningkatkan layanan penggunan digital. Dengan adanya hasil penelitian ini maka siswa pada khususnya dan masyarakat pada umumnya dapat memperoleh informasi dengan mudah dan user dari akademisi akan mudah untuk mendapatkan informasi sebagai pendukung untuk reseach.

Adapun hasil dari penelitian ini sebagai berikut:

a. Bagi pengguna layanan perpustakaan, hasil kegiatan penelitian ini dapat memberikan manfaat seperti memudahkan pengguna layanan perpustakaan dalam mencari informasi koleksi bahan pustaka tanpa harus datang ke perpustakaan karena dapat diakses melalui internet. Dapat merasakan kepuasan atas pelayanan, dan kenyamanan karena diterapkannya konsep E-CRM, sehingga menciptakan atau menambah minat membaca.

b. Dengan perangkat lunak ini, pengguna layanan perpustakaan dapat dengan mudah mengakses semua informasi perpustakaan, karena dapat diakses dimanapun, kapanpun tanpa terbatas dengan ruang dan waktu

c. Petugas perpustakaan dapat dengan mudah memonitoring pelayanan perpustakaan, sehingga jika terjadi ketidakpuasan user, dapat langsung dilakukan evaluasi.

d. Dengan adanya sistem ini maka dapat menjalin relasi dengan perpustakaan lain, bahkan bisa menjalin kerjasama.

e. Dengan konsep E-CRM maka pengguna perspustakaan akan mendapatkan update data perpustakaan secara real time. Misalnya ada buku terbaru, jurnal terbaru atau majalah terbaru. Dengan update informasi secara real time maka akan dapat menarik minat membaca.

\section{Pustaka}

[1] A. Ibrahim and M. Afrina, (2011) "Pengembangan Model Perpustakaan Berbasis Teknologi Informasi untuk Meningkatkan Kinerja Layanan Perpustakaan dan mewujudkan perpustakaan ideal berbasis digital di Fasilkom Unsri," in Jurusan Sistem Informasi Fasilkom Unsri, Palembang.

[2] A. Kosasish, (2009) "Otomasi Perpustakaan Sekolah: Sebuah Pengenalan," Perpustakaan Universitas Negeri Malang (UM), pp. 1-13.

Rancang Bangun Electronic Costumer Relationship Management (E-CRM) Sebagai Sistem Informasi Dalam Peningkatan Layanan Perpustakaan Digital SMAN 1 Sakra 
[3] Abdulloh, Rohi. 2016. Web Programming. Jakarta : PT Elex Media Komputindo

[4] D. Darmawan, (2001) Manajemen dan Tata Kejra Perpustakaan Sekolah, Jakarta: Gramedia Widasarana Indonesia.

[5] G. Subrata, Perpustakaan Digital, Malang: Pustakawan Perpustakaan UM, 2009.

[6] Hidayatullah, P dan Kawistara Khairul, J. Pemrograman web. Bandung: Informatika Bandung.

[7] Husda, NE dan Wangdra, Y. (2016). Pengantar Teknologi Informasi, Jakarta : Badouse Media.

[8] M. Afrina, (2012) "Pengembangan Model Sistem Informasi Perpustakaan Dengan Teknologi Informasi Berbasis Wireless Aplication Protocol (WAP) pada UNSRI," Jurusan Sistem Informasi, Fasilkom Unsri, pp. 1-9.

[9] Mulyadi. 2016. Pengelolaan Perpustakaan Digital

[10] S. Darudiato, Y. D. Puji, D. Angelina and D. Margaretha, (2006) "Analisis dan Perancangan Sistem Aplikasi Customer Relationship Management Berbasiskan Web (Studi Kasus: PT. Fajar Buana Internasional)," Seminar Nasional Aplikasi Teknologi Informasi, pp. E61-E66.

[11] S. Muasaroh, (2007) "Peran Perpustakaan Digital di Era Global," Makalah Seminar Pustakawan SMA 1 Kendal, pp. 2229.

[12] Shalahuddin, M dan Rosa, A, S. 2015. Rekayasa perangkat lunak terstruktur dan berorientasi objek. Bandung : Informatika Bandung

[13] Siswanto "Manajemen Perpustakaan Digital". [Online]. Available: https://mkpd.files.wordpress.com/2 007/07/sinopsis-buku-manajemenperpustakaan-digital.pdf.

[Accessed 16 Maret 2019].

[14] SP-SSH:, A. Widjanarti, A. Utami, E. S. Prianto, R. Ramelan and W. Purwanti, (2004) "Pengembangan Prototipe Sistem Customer Relationship Management Untuk Travel Agent," Fasilkom UI, Depok.

[15] Subagia, Anton. 2016. Membuat web dengan php 7 dan database pdo mysqli. Jakarta : PT Elex Media Komputindo
[16] Tim EMS. 2014. Teori dan praktik phpmysql untuk pemula. Jakarta : PT Elex Media Komputindo.

[17] W. A. Tunggal, (2009) Balance Scorecard: Mengukur Kinerja Bisnis, Jakarta: Harvarindo.

[18] Waskito, Dwi Andi. 2012. Perancangan Sistem Informasi Perpustakaan Pada SMK Negeri 2 Purworejo Menggunakan Barcode. Halaman : 1-16.

[19] M. Afrina, A. Ibrahim, 2013. "Rancang Bangun Electronic Costumer Relationship Management(E-CRM) SebagaiSistem Informasi Dalam Peningkatan Layanan Perpustakaan Digital Fakultas IImu Komputer Unsri" Jurnal Sistem Informasi (JSI), Vol 5, No. 2, pp. 629-644. 